\title{
ПРОБЛЕМЫ ЛИНГВОЭКОЛОГИИ РУССКОЙ РЕЧИ
}

Важной составляющей духовного и культурного наследия нации является язык. Кроме того, русский - это язык титульной нации, входит в клуб мировых языков, обладает статусом государственного языка Российской Федерации. Отсюда очевидна необходимость заботы о лингвоэкологии русской речи.

Разное время выдвигает различные угрозы экологии речи. В XX в. нарушения экологии речи были обусловлены отказом от традиций русской культуры и моральных ценностей. За таким отказом, последовало искоренение знаков православия в русской языковой картине мира, переименование улиц и площадей, содержавших названия религиозной тематики (многие улицы и площади ранее получали название по имени церкви, возглавлявшей данную местность).

Знаки христианства в языковой картине мира устранялись из письменных текстов: вновь набираемые в типографии произведения литературы содержали строчное обозначение имени Бога; изымались эпизоды, так или иначе связанные с теологическим моментом. В резонансном фельетоне Вл. Волина «И шестикрылый кое-кто» (1983), опубликованном в «Литературной газете», сатирик анализировал показательный факт: в сборнике стихов А. Блока, опубликованном издательством «Детская литература», слово церковной тематики ангел было заменено на неопределенное местоимение ктото: Свирель запела на мосту, / И яблони в цчвету,/ И кто-то поднял в высоту/ Звезду зелёную одну (Летний вечер).

Иронизируя, Вл. Волин предложил произвести и другие замены, напр., стихотворение А. Пушкина в детском издании творчески видоизменить: И шестикрылый кое-кто/ На перепутье мне явился. А в поэме М. Лермонтова, подготовленной для детей, написать: Печальный кто-то, дух изгнанья,/ Летал над грешною землёй.

Попутно заметим, что последнее было неактуальным для советской «ревизии» традиционных ценностей: разрушение христианства в русской культуре не касалось уничтожения демонического пантеона. В частности, 
поэму М. Лермонтова «Демон» в школе изучали без купюр. Примечательным является и факт из рассказа В. Шукшина, в котором персонаж, размышляя о вере в Бога, уточняет, мол, не знаю точно, верю ли, но вот черти есть, это точно. В XX в. демонический пантеон беспрепятственно изучался и обсуждался, но вот что значат слова $\partial y x$, духовность в параграфе школьного учебника литературы «Духовные искания Пьера Безухова» не раскрывалось. Школьные учителя эту проблему обходили молчанием или не раскрывающим сути многословием.

Последствия отказа от традиционных моральных ценностей в настоящее время иногда проявляются в комических формах. Школьники в сочинении на тему «Что значит сила духа?» пишут, что это такой сильный дух, который одержал человека и его трудно изгнать. Ошибка обусловлена контаминацией, не различением устойчивых сочетаний сила духа и нечиcmыıй дуx. Такое нарушение лингвоэкологии русской речи А. П. Сковородников именует как проблему фразеологических утрат (Сковородников 2014: 148).

Конец XX в. ознаменовался тем, что общество начало осознавать последствия отказа от духовных ценностей. Именно в это время в России формируются прикладные исследования в сфере защиты русского языка, среди которых - лингвоэкология. В начале XXI в. эта отрасль прикладной лингвистики уверенно формирует свой понятийный аппарат; по лингвоэкологии публикуются статьи, издаётся словарь (Сущенко 2011), журнал «Экология языка и коммуникативная практика»; школьные учителя готовят проекты по названной проблеме.

Важным термином понятийного аппарата лингвоэкологии является лингвочинизм. Этико-речевая ошибка, в которой говорящий передаёт негуманное, циническое отношение к объекту речи (Сковородников 2005: 402). Например, название заметки в одной из самарских газет о спортсмене-прыгуне, который спас тонущего, но сам погиб, - «Допрыгался». Безусловно, лингвоцинизмы есть печальное сопровождение человеческой речи, его моровая язва. Собирать факты лингвоцинизмов для простых сетований: это лингвоцинизм, и это плохо, было бы наивностью и пустой тратой времени. Гораздо важнее выявить ведущую угрозу того или иного времени.

В настоящее время происходит обновление морального потенциала русской культуры, возрождаются понятия, употребление которых совсем недавно вызывали у говорящих опасение выглядеть немодными, пафосными. Таковы слова-понятия героизм, патриотизм. Изменения, происходящие в обществе, в общественном сознании, находят отражение, в частности в прагматонимах. Так гордое название «Патриот» получила автомашина УАЗ, и это закономерно произошло в первое десятилетие XXI в.

Между тем в XXI в. пришли новые угрозы лингвоэкологии русской речи; они проистекают из глобализации, внедрения в сознание современных 
носителей русского языка превратного понимания толерантности, граничащего с вседозволенностью, лозунгов «Искусство свободно от политики», «Творчеству дозволено всё!». Эти лозунги оправдывают антигуманные проявления современной цивилизации, иронизирование над бедами человечества, подшучивание над смертью.

В 2012 г. эстонская газета разместила рекламу таблеток для похудения, эксплуатируя фотографии узников концлагеря и слоган: Айн, извай, драй... таблетки для похудения доктора Менгеле сотворят с тобой чудо с подписью: В Бухенвальде не было ни одного толстого!

В 2013 г. в программе «Смак» известный телеведущий И. Ургант допустил лингвоцинизм: Я порубил зелень, как красный комиссар жителей украинской деревни.

Публицистика изобилует фактами лингвоцинизмов. В погоне за читателем журналисты не останавливаются ни перед чем. Примечателен заголовок, посвященный жизни и деятельности убитого священника Павла Адельгейма: «Жил-был поп...». Когда на курсах повышения квалификации учителей в марте 2016 г. я предложила оценить этот заголовок с позиции лингвоэкологии учителям русского языка, не все специалисты слова сразу определили, что это лингвоцинизм. Учителя рассуждали: «Вроде бы такое лирическое, сказочное начало...».

Пришлось работать серией вопросов: «А вы знаете, что сказка Пушкина с таким названием не была опубликована при его жизни? Вы знаете, что такой номинацией не обращаются к священнику?».

В педагогической речи с лингвоэкологией тоже не всё благополучно. На протяжении 2014-2016 гг. я осуществила исследование оценочного жанра педагогического замечания. Применялись диктофонные записи уроков, метод включенного наблюдения и анкетирование.

Опрос-анкетирование охватил около 1.700 информаторов из городов: Самара, Тольятти, Сызрань, Кинель, Уральск, Москва и некоторых других. Картотека словоупотреблений жанра педагогического замечания составила 1910 единиц. Рассматривались положительные оценки и порицания. Мы разделяем точку зрения А. П. Сковородникова на бинарную природу лингвоэкологии (Сковородников 2014: 143), видим назначение лингвоэкологии не только в констатации негативных процессов в русской речи, но и в выявлении положительного, а также в определении путей оптимизации русского дискурса. Изучение ситуации оценивания на уроке явилось следующее:

В целом учителя позитивно общаются с обучающимися, находят для них добрые слова: Солнышки, лучики, зайчики, умнищы мои;

- Вот ответ, как орешки шеёлкает;

- Математику учить - ум в порядок приводить, как учил Ломоносов! (Учитель русского языка, Самарская область, с. Мало-Архангельское). 
Часто учителя самокритичны, применяют самоиронию:

- Ну что ты на меня смотришь? Лет десять назад бы - другое дело. А сейчас скорее задачу решай!;

- Я чайник, но не холодный. Я вскипевщий чайник» (Учитель алгебры, 53 г., Самара, Кировский район).

Применяют образную иронию:

- Ошибка на ошибке и ошибкой погоняет;

- Лень-матушка! (Учитель русского языка, 47 л., г. Кинель);

- Я тоже могу говорить не в тему: «Динозавр!» (Учитель географии, 28 л., Самара, Кировский район).

Между тем имеют место и деструкции речевого поведения. Обобщая многообразие деструктивных примеров (1400 словоупотреблений), назовём некоторые причины возникновения и частотные, а также неочевидные лингвоцинизмы педагогического дискурса. Прежде всего, следует сказать о значительной стандартизированности, клишированности речи учителя на уроке, ср. с точкой зрения в (Антонова 2007; Карасик 1999). Дискурсивные характеристики коммуникации на уроке базируются на значительном количестве устойчивых, а потому окаменевших оценок, лингвоэкологическая ценность которых от этого не улучшается. Таковы, например, узуальные оценочные номинации: сибирский валенок, пенёк с глазами, мямля.

Стандартизированность порицания скрепляется привычкой, недоброй традицией резкого осуждения, тиражирует деструктивные фразеологизмы:

- Пишешь, как курица лапой!;

- Смотришь, как баран на новые ворота!;

- Стадо баранов!

Когда-то учитель сам услышал такой попрёк, а теперь воспроизводит его автоматически, не задумываясь. А ведь зооморфизмы, сравнение человека с животным однозначно квалифицируются как оскорбление. Ещё коварнее ведут себя учительские риторические вопросы, напр.:

- Чикчирикнулся, что ли?;

- Ты случайно не болван?;

- Что за бред сумастедшего?!;

- У тебя, что, вместо ног лапки кривые? Беги скорее! (Учитель физкультуры, 53 г., Самарская обл., с. Подъем-Михайловка).

Лингвистическая коварность вопроса заключается в том, что, спрашивая, говорящий не утверждает, тем самым с него будто бы снимается ответственность за высказывание. Известны случаи, когда на упрек родительницы «почему называете моего ребёнка дураком?» учительница отвечала: «Нет, я не называла дураком. Я спросила: «Ты что, дурак?»»».

Оставим за пределами работы случаи очевидного учительского непрофессионализма (сниженной лексики, брани, шуточек типа Чтоб тебя понять остаётся только выпить). Внимание исследователей педагогическо- 
го дискурса должны привлечь не столь очевидные, а потому более опасные лингвоцинизмы и деструктемы:

[Метафора, паразитирующая на идее инвалидности] - Cидите и делайте вид, что вы глухонемые (Чапаевск, 2011 г.);

[Гиперболы, паразитирующие на угрозе смерти] - Тебя сразу убить или nостепенно (Учитель географии, 36 л. Кошкинский р-н г. Самары);

- Что ты хочешь ему сказать? Если не скажешь, он умрёт? (Учитель химии, 33 г., Самарская обл., г. Кинель).

Деструктемы подобного вида достаточно частотны; в нашей картотеке составляют около $25 \%$ от общего количества номинаций деструктивного характера.

В целом, лингвоэкология педагогической речи - социально значимая проблема. Лингвоцинизмы педагогической речи ориентируются на привычку, недобрую традицию учительского порицания. Порицания в форме риторических вопросов следует квалифицировать как недобросовестный приём речевого манипулирования. Недопустимы деструктемы-метафоры, паразитирующие на идее инвалидности, деструктемы-гиперболы, основанные на угрозе смерти.

\section{Библиография}

Антонова Н. А. (2007), Педагогический дискурс: речевое поведение учителя на уроке, Саратов. Карасик В. И. (1999), Характеристики педагогического дискурса, «Языковая личность: аспекты лингвистики и лингводидактики», Волгоград, с. 3-18.

Сковородников А. П. (2005), Лингвоцинизмы, «Выразительные средства русского языка и речевые ошибки и недочеты», Москва, с. 402-403.

Сковородников А. П. (2014), К философским основаниям эколингвистики, «Экология языка и коммуникативная практика», № 2, с. 140-161.

Сущенко Е. А. (2011), Словарь-справочник лингвоэкологических терминов и понятий, Санкт-Петербург.

\section{Elena Ivanian}

\section{THE PROBLEMS OF THE LINGUOECOLOGY IN THE RUSSIAN SPEECH}

(Summary)

The characteristic of linguoecological problems in the Russian speech is given in the article The short review of the reasons which have caused violations of a linguoecology in the Russian speech in the 20 th century - the beginning of the 21 st century is carried out. It is shown that violations in linguoecology of the Russian speech in the 20th century have been caused by refusal of traditions of the Russian culture and moral values that has led to numerous phraseological oblivion. 
Destructions of the Russian discourse in the 21st century are caused first of all by globalization, an assumption of such type of tolerance which borders on permissiveness that leads to the facts of a dehumanization and as a result to violations in a speech of linguoecology. The results of a two years' research of a genre of the pedagogical remark (method of the included supervision, and also questioning of 1700 informants) are presented in the article; both positive examples of estimation at a lesson, and distructures of a pedagogical discourse are revealed. Dependence between bad tradition of pedagogical censure and rate of application of destructive phraseological units, zoomorphisme is shown. Охарактеризованы риторические вопросы как приём речевого манипулирования в педагогическом дискурсе; выявлены неочевидные деструктемы (деструктемы-метафоры, паразитирующие на идее инвалидности; деструктемы-гиперболы, базирующиеся на угрозе смерти). Rhetorical questions as reception of a speech manipulation in a pedagogical discourse are characterized; unevident distructures are revealed (the distructures-metaphors parasitizing on the idea of disability; the distructures-hyperboles which are based on threat of death).

Keywords: linguoecology, linguocynicism, destructure, phraseological loss, pedagogical discourse.

\title{
ПРОБЛЕМЫ ЛИНГВОЭКОЛОГИИ РУССКОЙ РЕЧИ
}

\author{
(Резюме)
}

В статье даётся характеристика проблемы лингвоэкологии русской речи. Осуществляется краткий обзор причин, вызвавших нарушения лингвоэкологии русской речи в XX в. - начале XXI в. Показано, что нарушения в лингвоэкологии русской речи в XX в. были обусловлены отказом от традиций русской культуры и моральных ценностей, что привело, в частности, к многочисленным фразеологическим забвениям. Деструкции русского дискурса в XXI в. вызваны в первую очередь глобализацией, превратным пониманием толерантности, граничащим с вседозволенностью, что приводит к фактам дегуманизации и как следствие к нарушениям в лингвоэкологии речи. В статье представлены результаты двухлетнего исследования жанра педагогического замечания (методом включенного наблюдения, а также анкетированием 1700 информаторов); выявлены как позитивные примеры оценивания на уроке, так и деструктемы педагогического дискурса. Показана зависимость между недоброй традицией педагогического порицания и частотностью применения деструктивных фразеологизмов, зооморфизмов. Охарактеризованы риторические вопросы как приём речевого манипулирования в педагогическом дискурсе; выявлены неочевидные деструктемы (деструктемы-метафоры, паразитирующие на идее инвалидности; деструктемы-гиперболы, базирующиеся на угрозе смерти).

Ключевые слова: лингвоэкология, лингвоцинизм, деструктемы, фразеологические утраты, педагогический дискурс. 